\title{
STUDENTS' PERCEPTIONS ABOUT FEEDBACK PRACTICES DURING ACADEMIC WRITING COURSE: A SURVEY STUDY
}

\author{
Esty Nurjanah \\ English Student, English Language Education Department, Faculty Of Psychology And \\ Sociocultural Sciences, Islamic University of Indonesia, Indonesia \\ Corresponding Author Email: 17322068@students.uii.ac.id
}

\begin{abstract}
A B S T R A C T S
In Indonesian context, there is still very little research regarding how students' voicing their perception on the use of feedback practices by their teachers. Therefore, to fill this gap, this research is aimed to describe students' perception through a survey about their experiences in dealing with feedback practices by their teacher. This study involved 75 students from English courses and college. The Responsive Pedagogy Questionnaire (RPQ) was used in this study. There were 24 items with 4 Likert points in data completion. To analyze the data, Microsoft Excel was used by the researcher. Findings showed that teachers' feedback practice matters to the students $(M=3.70)$. It means that the participants have positive responses toward teacher feedback practices. These findings have pedagogical implications that teachers of academic writing can consider not only to the instructions but also to the content or the material.
\end{abstract}

\begin{tabular}{l}
\hline A R T I C L E I N F O \\
\hline Article History: \\
Received: January, 2021
\end{tabular}

Revised: March, 2021

Published: June, 2021

\author{
Keywords: \\ Students' Perception, \\ Feedback, \\ Academic Writing, \\ Higher Education,
}

\footnotetext{
How to cite: Nurjanah, E. (2021). Students' Perceptions about Feedback Practices During Academic Writing Course: A Survey Study. Jo-ELT (Journal of English Language Teaching) Fakultas Pendidikan Bahasa \& Seni Prodi Pendidikan Bahasa Inggris IKIP, 8(1), 1-10. doi:https://doi.org/10.33394/jo-elt.v8i1.3397
}

\section{INTRODUCTION}

Feedback practice is necessary for the teaching and learning process to students for improvement. Current studies on feedback issues in higher education reached the following areas related to the use of feedback practices on students' learning process. Ruegg (2014) investigated teacher feedback and peer feedback in Japan high school context. They found that teacher feedback affected English Foreign Language students' writing self-efficacy. It shows that students who received teacher feedback tend to be able to increase their confidence in aspects of writing ability more than students' that perceived peer feedback. However, Wang (2016) found that Chinese university teachers of EFL provided both oral and written feedback practices to students' oral presentations. Teacher in his oral feedback given feedback related to the content and logical thought of students. Whereas, the teacher in his written feedback gave feedback related to the problems of students' PowerPoint design. The teacher did not give much attention to grammatical errors but rather than teacher focused on phonological errors. On the other hand, Deeley (2019) investigated the problem of students' disappointment with assessment and feedback. It pointed out about the variety of assessment and feedback because of misunderstanding and miscommunication between teacher and students'. From the current research, it is concluded that feedback has a significant role both as a way to assess students' writing mechanics and at the same time build students' logical reasoning. It is also uneasy in its implementation. Knowing that it has a side effect of 
misunderstanding between students and teachers. Thus, having studies on issues about feedback is necessary to do due to its important roles as mentioned before.

In the Indonesian context, feedback practices have been conducted in some schools and universities. Susanti (2016) investigated students' perceptions toward effective feedback based on their proficiency level that feedback from the lecture is effective in writing form and feedback from the peer is effective in oral form. However, Widiastuti (2019) found that teachers gave both positive and negative feedback. Students perceived negative when the teacher gave feedback directly in front of the class that made students feel being mentally judged in front of others. Some students perceive positive feedback because it can help them develop critical thinking and enhances their motivation to improve their learning. Students' ability about academic writing skills in Indonesia is still low. It shows that there is a possibility of a lack of feedback exposure in the class and outside the class. When there is an effective feedback exposure instead of giving meaningful feedback, teachers give judgment that made students down or whether students use the feedback or not. According to Widiastuti (2019) that students perceived negative feedback because it was given in front of the class that probably was not used by students. Thus, research about feedback practices in higher education especially for academic writing is still needed in the Indonesian context.

However, there is still very little research conducted in the Indonesian context regarding how students' voicing their perceptions on the use of feedback practices by their teachers. Therefore, to fill this gap, this research is aimed to describe students' perceptions through a survey about their experiences in dealing with feedback practices by their teachers. It is important to listen to how students perceive the feedback since feedback is expected to enhance students' performance through the accurate and communicative diagnosis of students' work. It is expected that the feedback should not bring more confusement to the students.

The objective of this research is to describe the students' quantitative perceptions about feedback practices that students' received on their academic writing assignments. The results of this study will contribute to students' perception about feedback that they received from their teacher and this research is useful to know the impact of feedback on students language learning and for language teachers to be more aware of the importance of giving the student the feedback to support students' learning outcome.

Feedback practice is an essential aspect of both teaching and learning because it can help students understand the learning goal and diagnosing problems with students' work. Feedback is conceptualized as information provided by an agent (teachers or peers) about an individual performance (Hattie \& Timperley, 2007). The purpose of feedback is to reduce the discrepancy between where students are and where teachers want students to be. In addition, Ur (1996) stated that feedback as information given to the students' performance of the task with the aim to improve students' performance. To this extent, the author agrees that feedback is defined as information that is given to individual performance which is used for improvement. It can be concluded that feedback is any information that is beneficial to be given about students' performance to enhance the future performance of the students.

There are two ways of feedback that can be given such as oral forms and written forms. Students in written feedback concerns about evaluating the task, while in oral feedback they provided suggestions for revision (Breg et al., 2006). Meanwhile, Harris, Brown, and Harnett (2015) explored the level of feedback directed throughout peer and self-assessments. They pointed out that most feedback is directed to the task level, while self-regulatory feedback is solely found on self-assessment. According to Hattie \& Timperley (2007), effective feedback must answer three questions. 1) Where am I going. The first question refers to a goal to achieve learning outcomes. 2) How am I going. The second question is related to progress feedback. Teachers provided information to students about their performance or task. 3) 
Where to next. The third question refers to students' next steps to improvement. Hattie \& Timperley (2007) classified feedback in four levels. First, feedback on task refers about how well a task is understood, providing information about a task, such as whether the task is correct or incorrect, leads to obtaining information and knowledge. Second, feedback on the process includes providing information about the process used to accomplish a task or create a product. Third, feedback on self-regulation involves providing information in relation to the performance that directs to self-evaluation. It focused on student's monitoring of their learning processes. Fourth, feedback on self refers to feedback about the self as a person ("You are a great student") like praise that can support the student but mostly does not help them to enhance learning.

Students' perceptions about teacher feedback may be different from one student with another. Tom (2013) reported that students view feedback as important in helping students' know the strength and weaknesses in writing. Students received a significant amount of teacher feedback on grammar. Ali \& Al-Adawi (2013) reported that students and teachers perceive the feedback positively. Students believe that both oral and written feedback is important to them, but they consider that written feedback is more effective than oral feedback. Furthermore, Zhan (2016) found that students' perception of teacher feedback was positive. Students thought they could learn a lot from the feedback and would improve their writing. Dargusch \& Davis (2015) argued that the relationship between lecturers and students influences students' perceptions about feedback. Additionally, by having a great relationship with teachers, students will have positive perceptions about feedback. Further, Vattoy \& Smith (2019) investigated students' perceptions about teachers' feedback as related to students' perceived self-regulation, external goal orientation, self-efficacy, and EFL. The relationship was linear between all factors that affected students who perceived their teacher feedback. From the empirical review above, It is concluded that students' perceived feedback practice positively because it can help students enhance their performance in the learning process.

\section{RESEARCH METHOD}

This study was quantitative research. The subjects of the study were 75 students of the academic writing course. The data was collected by asking the students to fill the questionnaire.

\section{Research Design}

This research used the survey research method which provides a description of attitudes, opinions, behaviors, or characteristics of the population by studying its sample (Creswell, 2014). This research was designed to describe students' perceptions by quantitatively about teacher feedback practices that students' received on their academic writing assignments.

\section{Population and Sample}

There were 92 numbers of the population in this research. Those are English department students in college and students in English courses in Yogyakarta. The sampling method that the researcher used was non-probability sampling. Thus, to achieve $95 \%$ confidence level, by referring to Slovin's formula as manifested in the Raosoft sample size calculator, there were 75 numbers of participants as the sample in this study.

\section{Instruments}

There is one instrument in this research, The Responsive Pedagogy Questionnaire (RPQ). The RPQ was originally developed by a research team for use in mathematics in lower secondary schools (Smith et al., 2016). The RPQ was adapted for the EFL subject by 
Vattoy \& Smith (2019). It consists of 24 items divided into 5 domains. Validity and Reliability on Perceived Teacher Feedback Practice 0.89 (items 1-6), Perceived External Goal Orientation 0.83 (items 7-10), Perceived Self-regulation 0.74 (items 11-14), Perceived Self-efficacy 0.89 (items 15-20), Perceived EFL Teaching 0.88 (items 21-24). The RPQ is scored with 4 Likert points starting from strongly disagree (1) to strongly agree (4).

\section{Data Analysis}

Data analysis techniques used Microsoft Excel to find out the Mean and Standard Deviation of the variables. After that, the result was presented in the form of charts. The researcher took the same appropriate steps with this research. First, provided an online form for the questionnaires. Second, distributed 24 items questionnaire to students through Google form. Third, download the data from the online questionnaire in the form of a Spreadsheet. The last, analyzed the data used Microsoft Excel 2016 to find Mean and Standard Deviation.

\section{RESEARCH FINDINGS AND DISCUSSION \\ Research Findings \\ 1. Demographic Survey Result}

a. Age

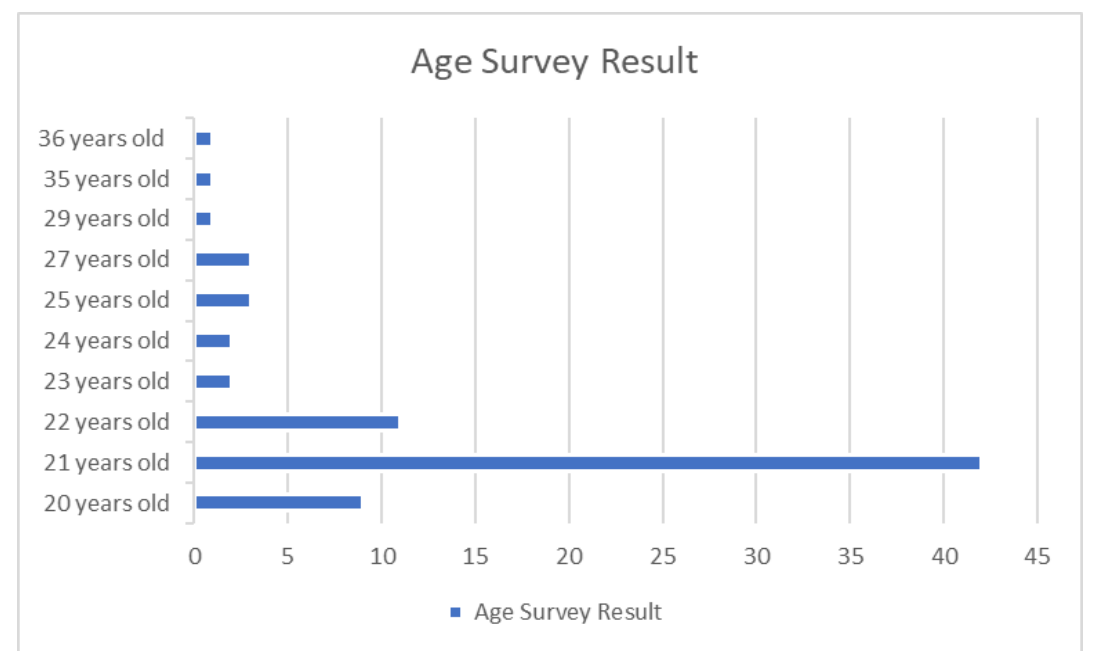

Figure 1. Age Survey Result

The overall age survey based on 75 participants has an age range of $20-36$ years old. The vertical line is the age of the participants and the horizontal line is the number of age. There were 9 people aged 20 years old, 42 people aged 21 years old, 11 people aged 22 years old, 2 people aged 23 years old, 2 people aged 24 years old, 3 people aged 25 years old, 3 people aged 27 years old, 1 people aged 29 years old, 1 people aged 35 years old and 1 people aged 36 years old.

\section{b. Gender}
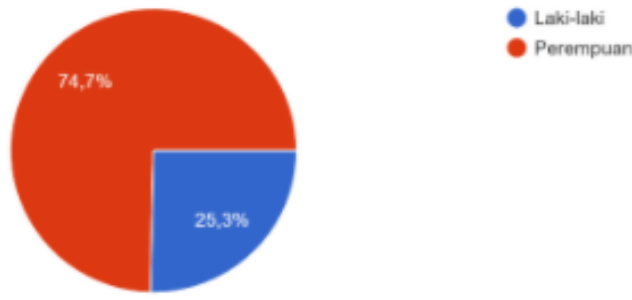

Figure 2. Gender Survey Result 
The overall gender survey result based on 75 participants found that 56 $(74,7 \%)$ participants were female and $19(25,3 \%)$ were male.

\section{The Overall Survey Result}

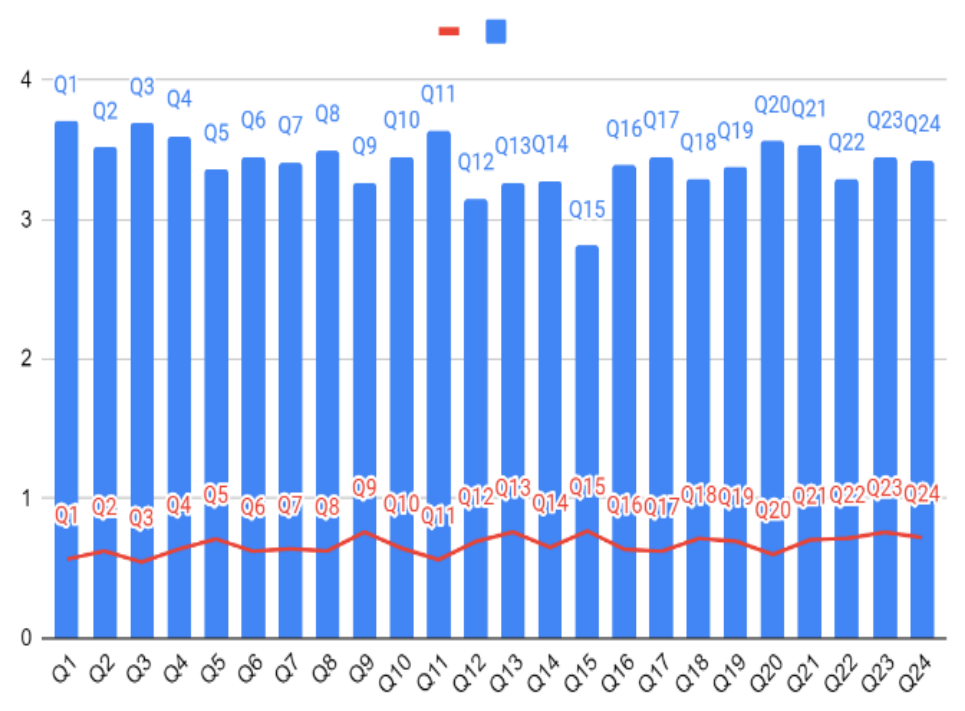

Figure 3. The Overall Survey Result

The overall survey result. The vertical line is Likert points and the horizontal line is the questions. The highest mean is Question number 1 with the results of Mean=3.70 and $\mathrm{SD}=$ 0.56 of which the statement is "The feedback I receive from English teachers helps me understand the task better". The lowest mean is Question number 15 with the results of Mean $=2.81$ and $\mathrm{SD}=0.76$ of which the statement is "I am confident that I understand the most complicated material taught by the teacher".

\section{Perceived Teacher Feedback Practice}

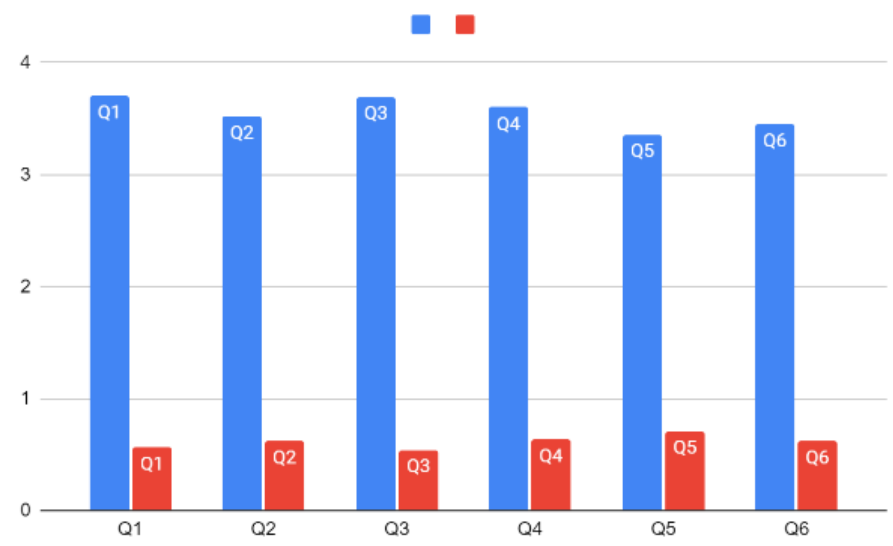

Figure 4. Perceived Techer Feedback Practice Result

Perceived Teacher Feedback Practice Result. The vertical line is Likert points and the horizontal line is the questions. The highest mean is Q1 with the results of Mean= 3.70 and $\mathrm{SD}=0.56$ of which statement is "The feedback I receive from English teachers helps me understand the task better". The lowest mean is Q5 with the results of Mean=3.36 and SD= 
0.70 of which the statement is "When I receive back tests or tasks in English, I am told what I need to practise more to do better next time".

\section{Perceived External Goal Orientation}

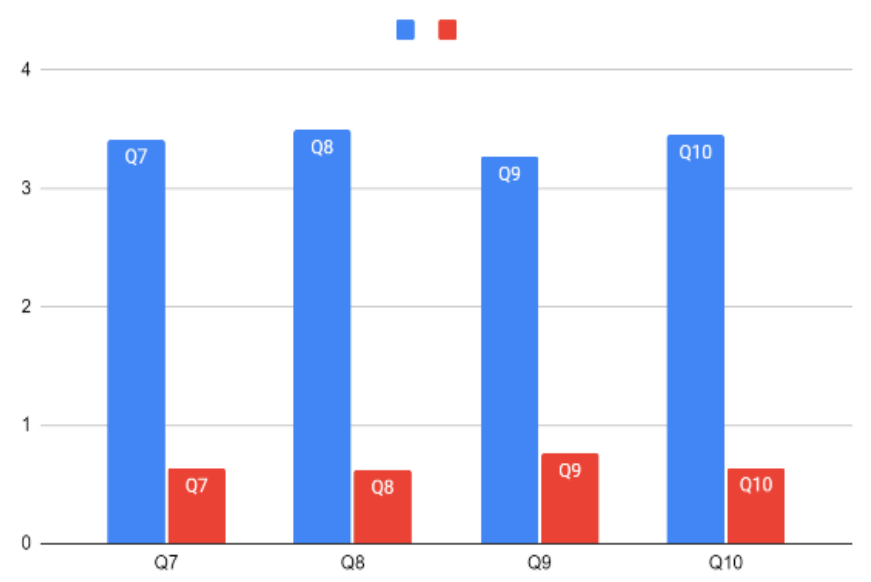

Figure 5. Perceived External Goal Orientation Result

Perceived External Goal Orientation Result. The vertical line is Likert points and the horizontal line is the questions. The highest mean is Q8 with the results of Mean= 3.49 and $\mathrm{SD}=0.62$ of which the statement is "I receive enough help to understand what I need to learn in English". The lowest mean is Q9 with the results of Mean $=3.26$ and $\mathrm{SD}=0.75$ of which the statement is "The teachers help me set learning goals in English".

\section{Perceived Self-regulation}

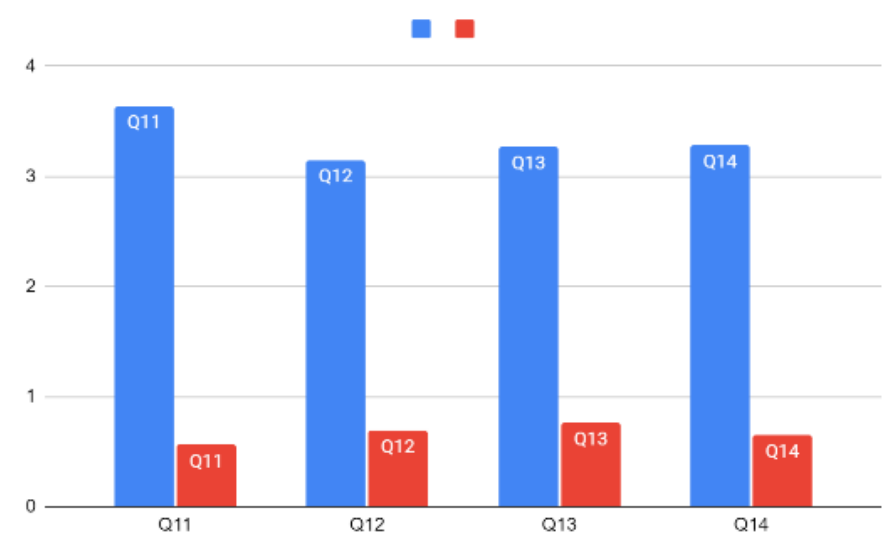

Figure 6. Perceived Self-regulation Result

Perceived Self-regulation Result. The vertical line is Likert points and the horizontal line is the questions. The highest mean is Q11 with the results of Mean=3.64 and SD=0.56 of which statement is "When there is something I do not understand in English, I try to find information that could make it clearer". The lowest mean is Q12 with the results of Mean= 3.14 and $\mathrm{SD}=0.69$ of which the statement is "When I work with English, I force myself to check if I remember what I have learned". 


\section{Perceived Self-efficacy}

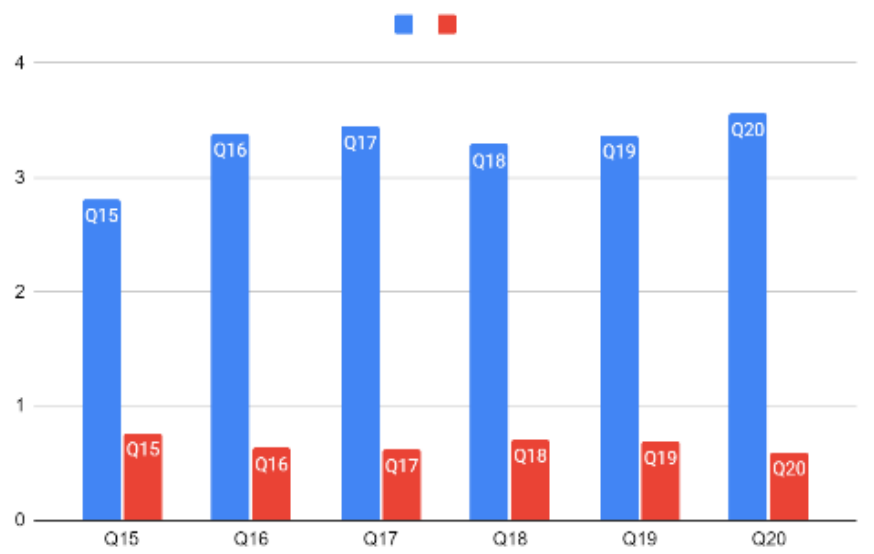

Figure 7. Perceived Self-efficacy Result

Perceived Self-efficacy Result. The vertical line is Likert points and the horizontal line is the questions. The highest mean is Q20 with the results of Mean $=3.56$ and $\mathrm{SD}=0.59$ of which statement is "If I decide to achieve tasks in English, I can do it". The lowest mean is $\mathrm{Q} 15$ with the results of Mean= 2.81 and $\mathrm{SD}=0.76$ of which the statement is "I am confident that I understand the most complicated material taught by the teacher".

\section{Perceived EFL Teaching}

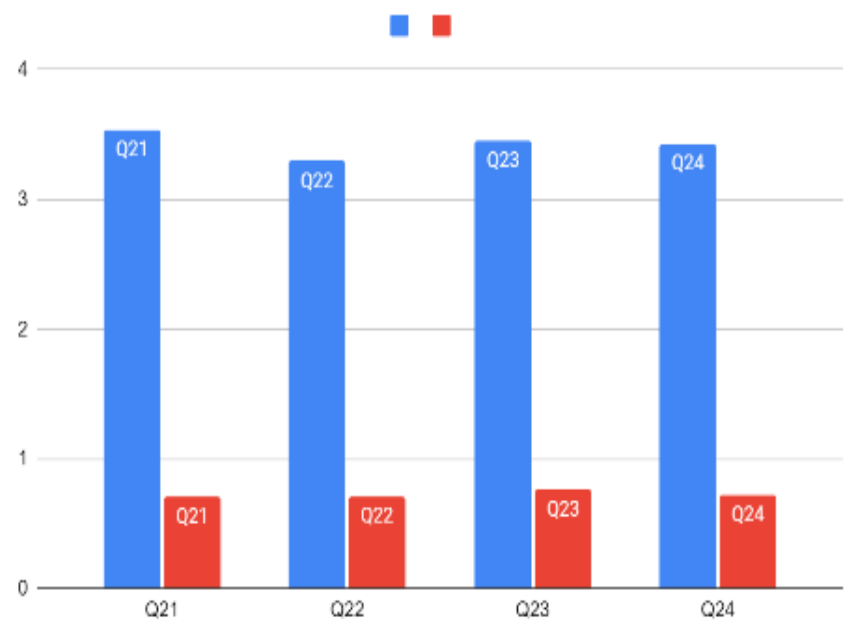

Figure 8. Perceived EFL Teaching Result

Perceived EFL Teaching Result. The vertical line is Likert points and the horizontal line is the questions. The highest mean is Q21 with the results of Mean= 3.53 and $\mathrm{SD}=0.70$ of which statement is "I look forward to teaching of English" and the lowest mean is Q22 with the results of Mean= 3.29 and $\mathrm{SD}=0.71$ of which statement is "I like teaching in English".

\section{Discussion}

The result of data analysis shows that the participants have positive responses toward teacher feedback practices. For students, having a positive response about feedback is important to help students understand the task better and gives students clear guidance to improve their learning. Zimmerman (1995) suggested that metacognition is not enough to support the learning process, there should be one additional factor which is self-regulation. 
As proposed by Vattoy \& Smith (2019), this factor also supports how students perceived feedback from their teachers. In accordance with these concepts, the findings of this research showed that teachers' feedback practice matters to the students $(M=3.70)$.

The findings of this research acknowledge that there are two significant issues following feedback delivery by teachers. The first one is that the feedbacks were seemed to be helpful in making students understand the instructions and task completion. However, it does not clearly make the students understand the materials. By this finding, it could be interpreted that there might be an issue on the task itself, maybe the content or how significant the task helps students understand the materials. There is why feedback tends to help understand only the instructions. The next possible issue is that since the study focuses on the feedback for academic writing thus the instructors and teachers focus on writing structure on the task. While academic writing itself more on skill-based courses instead of the content-based subject. Thus the feedback refers to writing a good essay, and how to write a good opinion. To some extent, if this research is extended to content-based subjects, the feedback can be on the material.

Hattie \& Timperley (2007) state that effective feedback must answer three questions. The first question refers to a goal to achieve learning outcomes (Where am I going). The second question is related to progress feedback (How am I going). The third question refers to students' next steps to improvement (Where to next). Thus, the feedback in academic writing should include, the first one is fit to the learning outcomes. The learning outcomes of academic writing are coherent, accurate, and relevant. The second one is how students proceed on the feedback, the teachers should not only give suggestions but also rechecking how the students work on each feedback or suggestion. The last one is to monitor how the students complete the task by finishing all of the feedbacks. By considering the result there is a possibility that the instructors and teachers of academic writing tend to accomplish only on the first questions that refer to the learning outcomes.

Based on the result of the questionnaire, Most of the students give positive responses to teachers' feedback practices. The students strongly agree that teacher feedback helps them understand the task better. There was relevant research written by Zhan (2016) in his journal "Written Teacher Feedback: Student Perceptions, Teacher Perceptions, and Actual Teacher Performance" stated that students' perception of teacher feedbacks was positive in the benefits they could have from the feedback and would improve their writing. It helped students much with grammar, organization, vocabulary and helped them find their problems. Further is Tom (2013) in his journal "Students' Perception and Preferences of Written Feedback in Academic Writing", the result showed that feedback from the teacher was effective and important to increase students' writing ability.

\section{CONCLUSION}

From the discussion, it is concluded that feedback practices have been appreciated as positive, however, it depends on the teacher's way of giving the feedback. It shows that students appreciate the feedback from their teacher and perceived feedback as positive but the feedback they receive is not enough to help them understand the complicated materials. These findings have pedagogical implications that teachers of academic writing can consider not only to the instructions but also to the content or the material. This research however was limited to the participants of the academic writing course in Yogyakarta. It might result differently when the data were collected in different cities. Thus, further study regarding the perception of feedback practices could be extended to those of participants in another city. 


\section{ACKNOWLEDGEMENT}

I express my deep gratitude to Mrs. Intan Pradita, S.S, M.Hum (Islamic University of Indonesia) without her precious advice, feedback, and her enthusiastic help, the paper would not have been completed.

\section{REFERENCES}

Ali, H. I., \& Al-Adawi, H. A. (2013). Providing effective feedback to EFL student teachers. Higher Education Studies, 3(3), 21-35. http://dx.doi.org/10.5539/hes.v3n3p21.

Berg, I. V., Admiraal, W., \& Pilot, A. (2006). Designing student peer assessment in higher education: analysis of written and oral peer feedback. Teaching in Higher Education, 11(2), 135-147. https://doi.org/10.1080/13562510500527685.

Creswell, J. W. (2014). Research Design: Qualitative, Quantitative, and Mixed. California: SAGE Publications, Inc.

Davis, S. E., \& Dargusch, J. M. (2015). Feedback, iterative processing and academic trustteacher education students' perceptions of assessment feedback. Australian Journal of Teacher Education, 40(1), 177-191. http://dx.doi.org/10.14221/ajte.2015v40n1.10.

Deeley, S. J., Fischbacher-Smith, M., Karadzhov, D., \& Koristashevskaya, E. (2019). Exploring the 'wicked' problem of student dissatisfaction with assessment and feedback in higher education. Higher Education Pedagogies, 4(1), 385-405. https://doi.org/10.1080/23752696.2019.1644659.

Harris, L. R., Brown, G. T., \& Harnett, J. A. (2015). Analysis of New Zealand primary and secondary student peer- and self-assessment comments: applying Hattie and Timperley's feedback model. Assessment in Education: Principles, Policy \& Practice, 22(2), 265-281. https://doi.org/10.1080/0969594X.2014.976541.

Hattie, J., \& Timperley, H. (2007). The power of feedback. Review of Educational Research, 77(1), 81-112. https://doi.org/10.3102/003465430298487.

Ruegg, R. (2018). The effect of peer and teacher feedback on changes in EFL students' writing self-efficacy. 46(2), 87-102. https://doi.org/10.1080/09571736.2014.958190.

Smith, K., Gamlem, S. M., Sandal, A. K., \& Engelsen, K. S. (2016). Educating for the future: a conceptual framework of responsive pedagogy. Cogen Education, 1(3), 1227021. https://doi.org/10.1080/2331186X.2016.1227021.

Susanti, R. (2016). Students' Perceptions Towards the Effective Feedback Practices in the Large EFL Writing Class Based on Participants, Gender, and English Proficiency Level. Journal of Advances in Linguistic , 6(3), 1063-1069. https://doi.org/10.24297/jal.v6i3.4673.

Tom, A. A., Morni, A., Metom, L., \& Joe, S. (2013). Students' Perception and Preferences of Written Feedback in Academic Writing. Mediterranean Journal of Social Sciences, 4(11), 72-80. https://doi.org/10.5901/mjss.2013.v4n11p72.

Ur, P. (1996). A Course in Language Teaching Practice and Theory. Cambridge: Cambridge University Press.

Vattøy, K. -D., \& Smith, K. (2019). Students' perceptions of teachers' feedback practice in teaching English as a foreign language. Teaching and Teacher Education, 85, 260268. https://doi.org/10.1016/j.tate.2019.06.024.

Wang, B., Teo, T., \& Yu, S. (2017). Teacher feedback to student oral presentations in EFL classrooms: a case study. Journal of Education for Teaching, 262-264. https://doi.org/10.1080/02607476.2016.1257507. 
Widiastuti, I. A., Mukminatien, N., Prayogo, J. A., \& Irawati, E. (2019). Students' Perception of Assessment and Feedback Practices: Making Learning Visible. International Journal of Sustainability, Education, and Global Creative Economic (IJSEGCE), 2(1), 1-8. https://doi.org/10.1234/ijsegce.v2i1.49.

Zhan, L. (2016). Written Teacher Feedback: Student Perceptions, Teacher Perceptions, and Actual Teacher Performance. English Language Teaching, 9(8), 73-84. https://doi.org/10.5539/elt.v9n8p73.

Zimmerman, B. J. (1995). Self-regulation involves more than metacognition: A social cognitive perspective. Educational Psychologist, 30(4), 217-221. https://doi.org/10.1207/s15326985ep3004_8. 